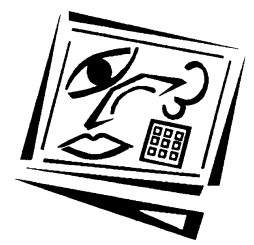

\title{
MICE 2.0: Designing multimedia content to foster active learning in a Malaysian classroom
}

\author{
Tse-Kian Neo, Mai Neo, Wai-Jing Kwok, Yeen-Ju Tan, \\ Chen-Haw Lai and Che Embi Zarina \\ Multimedia University
}

\begin{abstract}
With the strong emphasis of social constructivism, many educators are finding new ways to stimulate and enhance social activities within the classroom. One such method is the use of cooperative learning. A cohort of students worked in small teams cooperatively to complete an assignment while using blogs to document and reflect their work. Moreover, the students were required to use multimedia learning objects to enhance their knowledge in media production. The purpose of the study is to account for the students' perspective and experience learning in such an environment, known as Multimedia Integrated Cooperative-learning Environment (MICE) 2.0. A mixed method design approach was employed that included tests, survey and open-ended questions to gauge their learning ability, and attitudes about working in groups and using blogs in their learning process. The results showed that while the existence of the five cooperative components were crucial for a successful cooperative learning structure, the findings indicated that respect, tolerance and communication are important aspects in working successfully in teams. They also found using blogs as a good learning experience to use for reflecting upon their work. Overall, the learning environment showed that cooperative learning using technology allowed the students to gain lifelong learning skills that are important for their future endeavours.
\end{abstract}

\section{Introduction}

Currently, the pedagogical shift towards student-centred learning has become the teaching strategy of choice for many classrooms. The objective of these student-centred environments is to allow students to actively construct their own knowledge using their past experiences and prior knowledge and to acquire skills such as organisational, communication and teamwork skills to prepare them for the real world ahead of them. It states that learning is an active process and the learners construct knowledge from their past experiences, mental structures and beliefs that are used to interpret objects and events (Jonassen, 1994). This knowledge construction process is usually affiliated with the constructivist learning approach, which has its foundations from theorists such as Dewey (1896), Piaget (1952), Bruner (1985), Vygotsky (1978) and Papert (1980).

Research has found that students who actively participate in project-based learning enhance their capability of exploration and show improvement in their thinking skills (Krajcik, Blumenfeld, Marx, Bass \& Fredricks, 1998). One such project-based learning approach is cooperative learning. This student-centred concept is based on the social constructivist learning approach as propounded by Vygotsky (1978) who posits that the idea of learning resembles a type of "social activity". Students can learn by 
interacting with their peers and teacher to achieve their learning goals. Vygotsky (1978) also suggested that the use of language becomes crucial as it provides the learner with the tools to interact, socialise and discuss with other peers or members of the community. Therefore through talking with their peers as well as more experienced individuals, learning occurs (Gerlach, 1994). McWhaw, Schnackenberg, Sclater and Abrami (2003) posit that learning takes place when an individual interacts with people from different backgrounds, knowledge and experiences. Thus, the concept behind group-based learning is to provide a suitable learning environment for learners to socialise, interact and learn.

Jacobs and Hannah (2004) stated that the term "cooperative learning" was implemented back in the 1970s where a large amount of research and practical work occurred on how best to implement peer power for the benefits of learning. Practices such as "interactivity, activation of prior knowledge, connecting the theoretical to the experiential, as well as relevance and efficacy to assess information" have become more consistent in cooperative learning theory (Coutinho, 2007, p.2028).

Learning in a cooperative learning environment also promotes knowledge sharing as students will benefit from sharing of ideas instead of working individually (Dahley, 1994). Furthermore, Saddler (2008) posited that cooperative learning is a powerful teaching strategy that can increase peer to peer interaction as well as student attitudes towards learning. It prepares students for real world situations and may help counteract the effects of competitive testing and working alone ((Zimbardo, Butler \& Wolfe, 2003).

One of the benefits of learning cooperatively is that learners are forced to deal with each other face to face and this provides them with an opportunity for verbal discussion and problem-solving. Stevens and Slavin (1995) stated that the cooperative learning experience has proven to promote greater achievement in results and better retention, compared to an individual learning experience. As McNeese (2000, p.167) stated, "The idea of sharing individual knowledge through cooperative activities underlines the meta-cognitive/ cognitive benefits of having people work together." Therefore, cooperative learning strategies can result in better learning attitudes, as the students are given the opportunity to process knowledge and tasks together, develop more in-depth understanding of the subject matter, improve social skills and increase motivation towards learning.

\section{Cooperative learning model}

The idea behind cooperative learning encourages students to learn through group activities. As Jensen, Johnson and Johnson (2002) explained, cooperative learning is defined as a learning situation in which students working in groups can achieve the goals of an instructional activity only if the other students with whom they are working with achieve the goals as well. Instead of using traditional lecture methods where the lecturers "tell" students the information that they have to "remember," students themselves should get involved in an active learning environment, where they have to construct the knowledge on their own (Garfield, 1993). McConnell (2000) proposed that a cooperative learning environment should consists of tasks that are issue-based, where students set their own learning goals and negotiate their own meaning. He believes that such an approach will increase student autonomy and deep learning strategies. 
Components of cooperative learning include five aspects as suggested by Johnson and Johnson (1994a). They include positive inter-dependence, individual accountability, promotive interaction, interpersonal skills and group processing, all needed in the environment. Through positive inter-dependence, members of the groups must be made aware of the importance of their roles in the team. By realising that the success or failure of their project will depend on them working together, groups must perceive their goals to be inter-related to work together to reach their learning objectives. Johnson and Johnson (1999) determined nine ways in which positive inter-dependence can be structured, one of which is role inter-dependence. In this structure, each person in the team takes on a role with certain responsibilities which then support and contribute to the completion of the task together.

Besides depending of each other, individuals within the team will also need to be take responsibility for their own actions. According to Millis (2002), each individual member of the group must be individually responsible for their own academic performance. Tanner, Chatman and Allen (2003) stated that randomly assigning roles to students provides each member in the group "an entry point for participation" that will allow them to assume their individual responsibility accordingly. Stanton and Fairfax (2007) argued that building a team's productive manner is the first step in encouraging individual accountability in cooperative learning environments.

Being individually accountable for their actions will encourage members to feel motivated to contribute to the team. Also, increased individual accountability tends to increase the perceived positive inter-dependence among group members (ArcherKath, Johnson \& Johnson, 1994a). In order to enhance accountability, Millis (2002) suggested that marks or grades that are assigned must also reflect the individual contributions. If a person within the team is made to feel that he or she is needed and properly rewarded, he or she will be more inclined and motivated to cooperate with the rest of the members (Johnson \& Johnson, 2003).

Promotive interaction, sometimes also known as face to face interaction, allows the team to build and maintain relationships with each other. Being supportive and encouraging one another creates a healthy working environment for members. This includes helping one another with problems and supporting each other, which can encourage each member to do their best. Johnson and Johnson (1989) explained that by encouraging promotive interaction, members are more likely to be personally committed to each other to accomplish the group goals.

By requiring students to work in groups, the need to learn to work as a team arises. Because many students do not usually work in a cooperative learning environment, they may lack group and social skills. These social skills are not necessarily inherent, but can be taught and learnt. Social skills such as communication, leadership, trust building, decision making as well as conflict management, are needed to have effective team building (Johnson, Johnson \& Smith, 1991; Smith 1995). Through discussions and effective group communications, members within the groups are able to sustain the overall inter-relationship among the group and therefore, cooperating effectively with one another. Tanner et al. (2003) also stated that these social skills should include listening to views of all members, providing constructive criticism, learning to ask clarifying questions and being open to alternative views. Moreover, being respectful to each other and their thoughts and ideas enhances team spirit in a group. 
Johnson et al. (1991) suggested that group processing involves the group members discussing their contribution and efforts and maintaining productive working relationship. Allowing the group to reflect on their work provides them with the knowledge of how well they are progressing and what needs to be done or modified (Gaikwad, 1996). Tanner et al. (2003) suggested that over time, by engaging in group processing, students will improve their cooperative learning skills. Learning how to broach stressful situations within a group will provide experience in resolving conflicts and enhancing team relationships. Moreover, they proposed that successful group processing can be achieved through explicit conversation or written responses to the group by the teacher. Johnson and Johnson (1994a) recommended that teachers may need to observe and listen to students' discussions, in order to provide valuable information on how much the students understand about the tasks at hand, the content as well as the required instructions and the strategies being learnt.

According to Smith (1995), in order to differentiate good cooperative learning structures from weak ones, five basic elements (Table 1) need to be present in the environment and must be taken into account throughout the learning process. Johnson and Johnson (1994b) indicated that successful implementation of cooperative learning can lead to higher academic achievement, better interpersonal relationship among the learners and community and encourage learners to have positive attitudes towards the subject matter.

Therefore, this approach to learning can be used to enhance the learners' overall learning experience in a classroom compared with a conventional classroom environment. The skills learnt in such an environment encourages more students to work with each other and better prepare them for the job market by developing critical thinking skills, communication skills, organisation skills and others. Table 1 below illustrates the components of cooperative learning as well as the summary behind each component, while Figure 1 illustrates a simplified version with an action example.

Table 1: Cooperative learning - brief explanation (adapted and constructed based on Johnson, Johnson \& Holubec, 1994)

\begin{tabular}{|l|l|}
\hline $\begin{array}{l}\text { Positive inter- } \\
\text { dependence }\end{array}$ & $\begin{array}{l}\text { Each team members/learner's success is dependent on the } \\
\text { others being successful as well. }\end{array}$ \\
\hline $\begin{array}{l}\text { Individual } \\
\text { accountability }\end{array}$ & $\begin{array}{l}\text { Each member of the team is responsible and accountable for } \\
\text { his or her contribution. }\end{array}$ \\
\hline $\begin{array}{l}\text { Promotive } \\
\text { interaction }\end{array}$ & $\begin{array}{l}\text { Each member or learner is encouraged to interact with the } \\
\text { team by helping each other, solving problems, providing } \\
\text { constructive feedback, supporting and encouraging one } \\
\text { another. }\end{array}$ \\
\hline $\begin{array}{l}\text { Interpersonal } \\
\text { skills }\end{array}$ & $\begin{array}{l}\text { Each member or learner has the opportunity to communicate } \\
\text { their ideas and expressions to the group and to resolve any } \\
\text { conflicts that arises properly and constructively. }\end{array}$ \\
\hline $\begin{array}{l}\text { Group } \\
\text { processing }\end{array}$ & $\begin{array}{l}\text { Each member or learner is given the opportunity to cultivate } \\
\text { a good working relationship with their group members } \\
\text { through supporting and encouraging one another. Also, the } \\
\text { efforts and contributions to the groups by individuals are } \\
\text { made to feel appreciated. }\end{array}$ \\
\hline
\end{tabular}




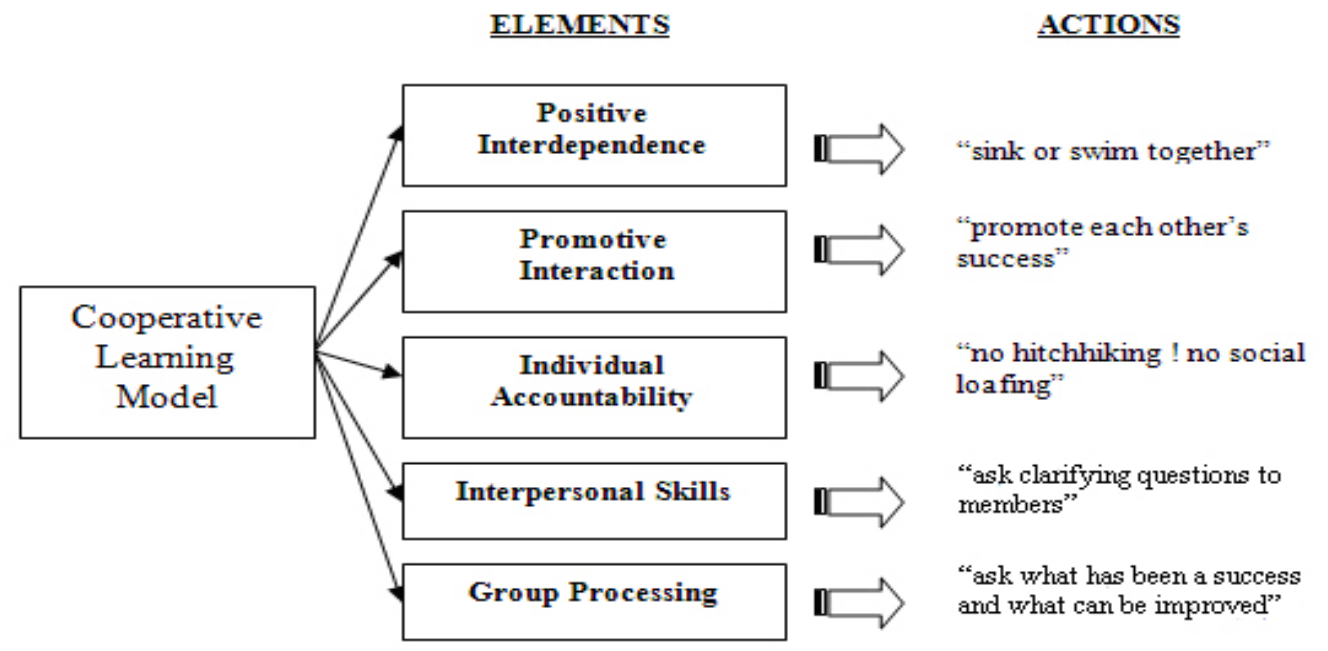

Figure 1: Five elements of cooperative learning (adapted and constructed based on Johnson, Johnson \& Smith, 1998)

\section{Social learning using Web 2.0}

With the availability of multimedia and current Web 2.0, socially interacting with one another through media rich environments has become a common trend to many 'digital natives'. Thus, using Web 2.0 tools allows learners to take advantage with current technology trends and encourages them to share knowledge and interact socially with their peers to enhance their learning processes. According to Goh, Quek and Lee (2010), the term Web 2.0 implies an interactive learning environment that can enhance communication between users. As Allen and Long (2009) explained, prior to the emergence of Web 2.0, many assumed that online tools served better as platforms for creating constructivist learning environments instead of just acting simply as transmission tools for information.

One such Web 2.0 tool is 'web-logs' or 'blogs'. Blogs are considered to be learning tools that can encourage autonomous, deep and reflective strategies (Fiedler, 2003) and as such are ideal for use in constructivist learning environments. The popularity of using blogs lies in the scope for interactivity (Williams \& Jacobs, 2004). Blogs help the students to share and express their opinions with the other members. It also serves as a tool to organise their work because learners are able to preview their work in progress online throughout their learning. Moreover, they are able to make comments and to receive other people's comment in order to improve their work and to increase discussions amongst learners. Since blogs provide the space for individuals to voice their opinions and expression, bloggers are given a sense of personal empowerment and belonging to the learning community at large (Farmer, Yue \& Brooks, 2008). Through the use of social interaction with blogs, learners are situated in a learning environment that can take place beyond the boundaries of the classroom.

However, in order to use blogs successfully as a learning tool, support by appropriate pedagogies is needed (Makri \& Kynigos, 2007). Integrating blogs together with a cooperative learning structure, allow cooperative learning to move outside the 
confines of the classrooms and enables students to continue learning in their teams at their own time and place. Smith (1995) encouraged teachers to provide students with means for the group to discuss and monitor their progress. By doing so, groups are able to evaluate their contribution as well as their progress, which in turn will enable them to maintain team coherence more effectively. Moreover, using blogs to supplement cooperative learning allows students to be more open and free to comment on their team's work than in class, as they can take an additional perspective on group atmosphere (Huang, Huang \& Yu, 2011).

By taking advantage of the components of cooperative learning and the characteristics of blogging, to create a technology and media rich-environment that allow learners to cooperate with one another to achieve their learning goals, is the focus of this study. Hence, the MICE 2.0 or Multimedia Integrated Cooperative-learning Environment 2.0 was formed. Through combining technology and media into a learning environment, students are given the opportunity to use their social skills as well as their technoprowess, to learn together and acquire lifelong learning skills in preparation for the work life ahead of them.

\section{Method}

The purpose of this research is to study the students' perceptions and overall experience in this cooperative learning environment. The students were placed in a learning environment whereby they had to cooperate in small group while building a multimedia-based website. The project required each group to design and develop a website using available multimedia tools based on a course theme.

In addition to developing this site, students were required to use blogs as part of their process documentation. The blogs were used to allow the group to reflect on their work and to show progress in their development of their assignment. Overall the learning environment was coined as Cooperative-learning 2.0 as they utilised the tenets of cooperative learning set forth by Johnson and Johnson (1994a), as well as using currently available Web 2.0 applications such as blogs. Moreover, the students were using multimedia learning objects and professional multimedia development tools to design and develop multimedia application.

In the past, students were required only to develop personal websites, usually working in pairs. The shift towards using cooperative learning approach allows them to enhance their lifelong learning skills including teamwork skills as well as their organisational and communication skills. This was their first time using blogs as well as working in a group setting to develop multimedia applications.

\section{Sample}

The study was based on an undergraduate course entitled Digital Media 1. A cohort of students enrolled in the Bachelor of Management (with Multimedia) degree were required to take this course as part of the requirements for the multimedia content of their degree. The group were management students studying finance, management, economics and marketing, and this was the first class that introduced them to the processes of designing and developing multimedia.

Although these students were accustomed to using computers ands the web to study their management courses, they had not experienced any multimedia development 
tools and Web 2.0 tools in any of their previous courses. Therefore, this was their first time using multimedia and Web 2.0 to create multimedia content. The students were mainly first year students aged between 19 and 21 years. The total number of students in this course was $53(\mathrm{~N}=53)$, coming from a multi-cultural background including Malays, Chinese, Indian and other ethnic races from Malaysia, together with a few foreign students. This convenience sample was chosen as it was typical of the mix of university students in Malaysia.

\section{Class structure}

As there were fifty-three students, they were required to work in small groups consisting of 4-6 individuals. The purpose of the course is to give them with the opportunity to understand the digital content creation process and to do so, they had to design and develop a website using professional multimedia tools. These tools include Adobe Photoshop, Adobe Flash and Adobe Dreamweaver. The course was divided into two sections, the lecture section where they were exposed to knowledge and processes of digital content, and a tutorial section where they learnt basic skills in content development and software training.

The theme of this presentation of the course was 'Malaysian Culture and Heritage'. This broad based theme was chosen to provide them with a wide variety of choices for their website development. Each group was required to design a website based on an aspect of this theme which might include architecture, food, various sub-cultures and so on. The assignment lasted for the entire semester of 14 -weeks, and they were allowed to pick their own group members and group leaders. They were also asked to nominate a group name for their project and a group leader.

There were twelve groups in total. Each individual member was responsible for one of the main links of the website. In other words, if there were five members, their group website would contain five main links that each member was responsible for building. They were all assessed upon both group and individual contributions. The group contribution consisted of the overall planning and ideation of the website while the individual contribution involved their personal effort in developing the main link that has been assigned to them by their group. There were several activities they had to conduct to develop a proposal detailing their ideation and objectives. Further along, they had to develop a plan for production which included designs for their graphical user interface, their website structure as well as content of their website. They were also required to reference any material that they used from websites and to provide a detailed account of the tools used to develop the media as well as the website.

All these activities were documented in a group blog hosted by any of the free blog services on the Internet. Each blog consisted of several pages, depending on the number of people per group. If there were five members, there were five pages with each member being responsible for entries in that specific page. The students were allowed to pick any service but it had to allow the lecturer and other students to view them and comment on them. In other words, they had to have a comment link made available to and by accessed by the entire class.

In addition, students were required to use online multimedia learning objects to give them some understanding of the characteristics of digital media. One such learning object was "Digital Sound". These multimedia modules were given as replacements for lectures, allowing them to learn on their own and at their own pace. Figure 2 below 
illustrates the class structure of this Cooperative-learning 2.0 environment. Furthermore, Table 2 details the activities that took place within the environment.

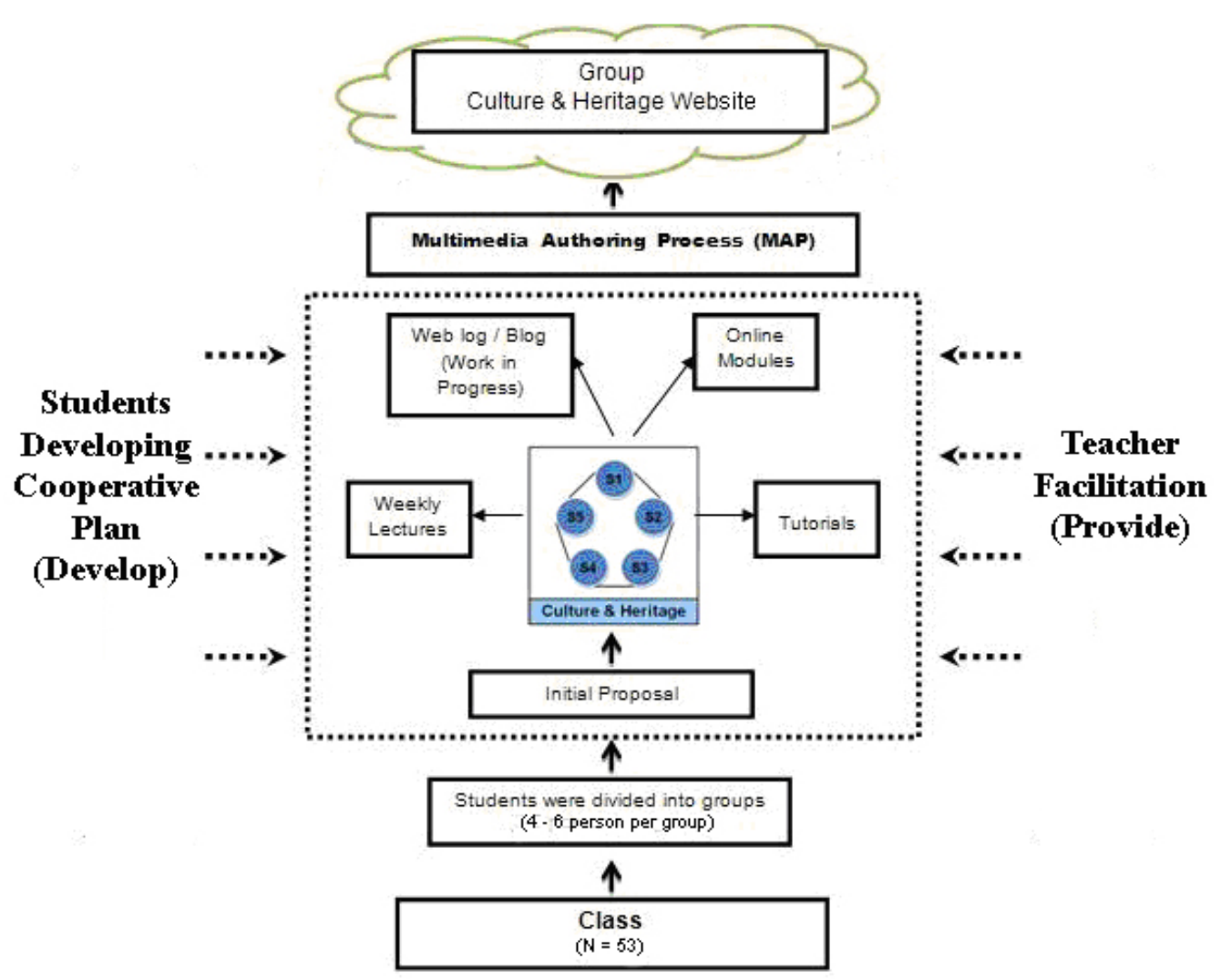

Figure 2: The structure of the Cooperative-learning 2.0 environment

Table 2: Activities that took place within the cooperative learning environment

\begin{tabular}{|l|l|}
\hline \multicolumn{1}{|c|}{ Activities } & \multicolumn{1}{c|}{ Description } \\
\hline $\begin{array}{l}\text { Forming } \\
\text { cooperative } \\
\text { teams }\end{array}$ & $\begin{array}{l}\text { In the beginning of the course, the students were encouraged to form groups of } \\
\text { their choice. The final project details were explained in class as well as } \\
\text { uploaded online for their use. The project required the students to form small } \\
\text { groups of 4-6 members and they had the opportunity and responsibility to find } \\
\text { their own team mates. Each individual member was responsible for one of the } \\
\text { main links of the website. In other words, if there were five members, their } \\
\text { group website would contain five main links that each member will be } \\
\text { responsible for building. They were all judged on both group and individual } \\
\text { contributions. Their tasks were to work together cooperatively to complete } \\
\text { their assignment. }\end{array}$ \\
\hline Initial proposal & $\begin{array}{l}\text { Once the groups were formed, they were to decide as a team an aspect of the } \\
\text { overall theme of their final project, "Malaysian Culture and Heritage". When a } \\
\text { topic had been decided, each team had to produce an initial proposal } \\
\text { containing the title of their project, team members and team leader, their } \\
\text { objective, target audience and references. }\end{array}$ \\
\hline
\end{tabular}




\begin{tabular}{|c|c|}
\hline $\begin{array}{l}\text { Teacher } \\
\text { facilitation and } \\
\text { multimedia } \\
\text { learning } \\
\text { environment }\end{array}$ & $\begin{array}{l}\text { During the course of the class, students attended lectures on the characteristics } \\
\text { and uses of digital media, as well as topics on content creation. Besides lectures, } \\
\text { students engaged with discussions and consultation sessions to clarify as well } \\
\text { as answer questions to assist them with their development and learning } \\
\text { process. Several multimedia learning objects were used to substitute for } \\
\text { conventional lectures. These multimedia learning objects allowed the students } \\
\text { to experience a media-rich and student-centred environment. These learning } \\
\text { objects were created following Gagne's Nine Events of Instructions which } \\
\text { therefore considered as a good lesson design (Gagne, Briggs \& Wagner, 1992; } \\
\text { Teoh \& Neo, 2007). One of the topics chosen for this multimedia learning object } \\
\text { was "Digital Sound" (see Figure 3). } \\
\text { The role of the teacher was to facilitate their questions regarding the } \\
\text { requirements of the project, problems with software and overall direction of the } \\
\text { project. The lecturer was also required to comment on all the students' blogs } \\
\text { and to give suggestions on the progress of their development. }\end{array}$ \\
\hline $\begin{array}{l}\text { Developing } \\
\text { cooperative } \\
\text { plan using } \\
\text { blogs }\end{array}$ & $\begin{array}{l}\text { Through discussions and group meetings, each group eventually developed } \\
\text { their own cooperative plan for implementation. Each blog consisted of several } \\
\text { pages, depending on the number of people per group. If there were five } \\
\text { members, there were five pages and each member was responsible for entries } \\
\text { in that specific page. The plan would include their goals, design strategies, } \\
\text { storyboards, flowcharts and information on their topic of interest. All this } \\
\text { information was documented in entries on the blogs of each team (see Figure } \\
\text { 4). Each team was required also to update their blog entries regularly and to } \\
\text { post images, references, their sketches, graphical user interface (GUI) layout } \\
\text { and site maps for their website, to document the development of their } \\
\text { cooperative plan. Students were also encouraged to view other groups' blogs } \\
\text { and to provide constructive comments to enhance designs and website } \\
\text { development. Also, the lecturer provided guidance and comments on their } \\
\text { blogs, including approving their cooperative plan, directors, design and } \\
\text { technical suggestions. However, it was up to the groups to decide on their } \\
\text { implementation process. }\end{array}$ \\
\hline $\begin{array}{l}\text { Multimedia } \\
\text { authoring } \\
\text { process (MAP) }\end{array}$ & $\begin{array}{l}\text { In order for the teams to create their websites, they applied the steps provided } \\
\text { in the Multimedia Authoring Process (Neo, Neo \& Rafi 2004). The MAP was used } \\
\text { as the development model and guidelines for the students to construct their } \\
\text { multimedia-rich website, using what they have learnt in this class and prior } \\
\text { knowledge. The steps in the MAP included the pre-authoring process (media } \\
\text { acquisition, media conversion to digital and media editing), authoring process } \\
\text { (synchronising media according to plan, adding interactivity and special } \\
\text { effects, and testing) and post-authoring process (conversion to Shockwave Flash } \\
\text { and burning the finished application to a CD). The teams had to rely on each } \\
\text { other to create a complete website. They had to solve problems on their own or } \\
\text { take constructive comments from other groups in the class. }\end{array}$ \\
\hline $\begin{array}{l}\text { Submission of } \\
\text { completed } \\
\text { website and } \\
\text { updated blogs }\end{array}$ & $\begin{array}{l}\text { Once the teams had completed their assignment, they submitted a report } \\
\text { containing their modified proposal, flowcharts and any material they used in } \\
\text { developing their application, as well as their final application (see Figure 5) to } \\
\text { the lecturer. They had to have their blogs updated and ready for final } \\
\text { assessment. }\end{array}$ \\
\hline
\end{tabular}

\section{Learning outcome}

The learning outcome of this study was a website which showed the student's ability to design and develop it following the theme of the course, working cooperatively in small groups. Besides their final output, they were to document their process in a blog for the class and the teacher to access throughout the course. The results of working in the Cooperative-learning environment are as shown in the figures below. 
Figure 3 depicts the multimedia learning object that the students have to learn from, while Figure 4 shows an example of a group blog. Figure 5 shows a sample screen picture of the results of their effort, and Figure 6 shows the website itself. It should be noted that these students did not have any background in design and did not possess any multimedia development skills prior to this course.

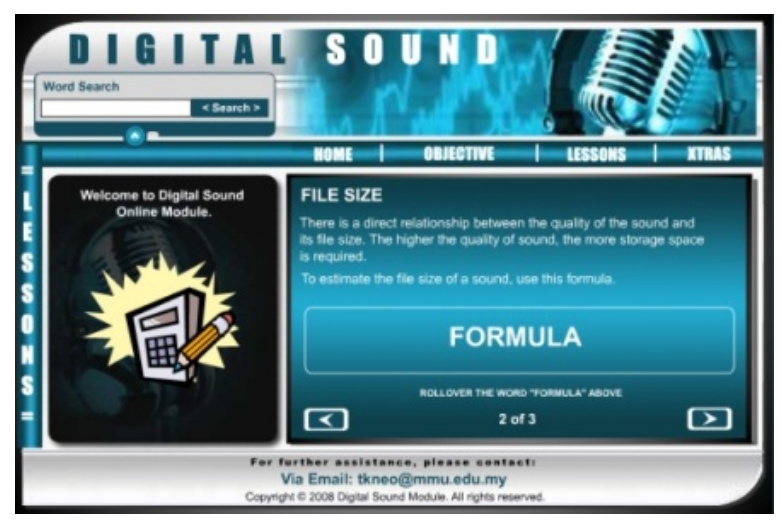

Figure 3: Online module "Digital Sound"

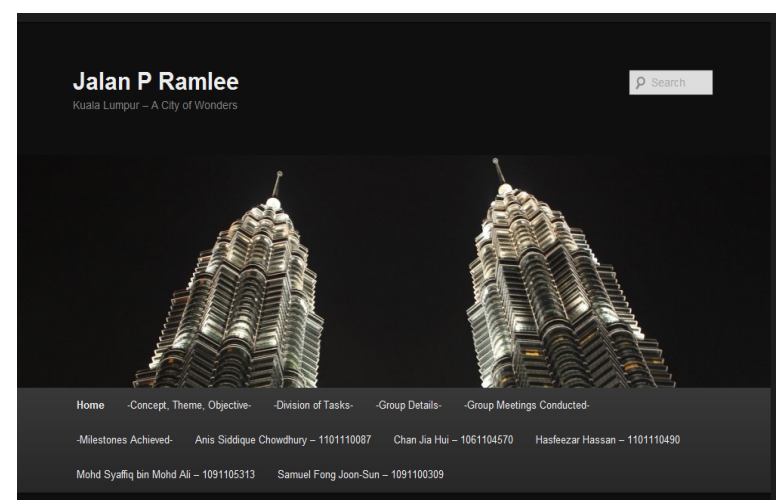

Figure 4: Screen picture from a student's blog

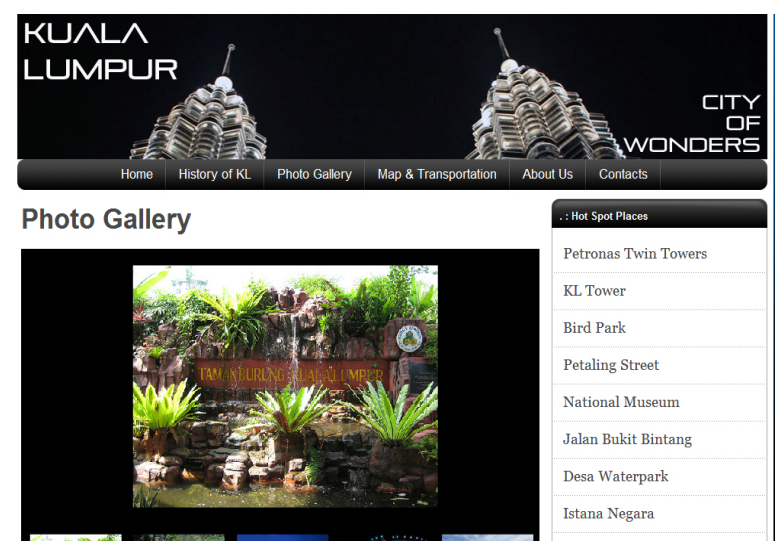

Figure 5: Screen picture from students' completed website 


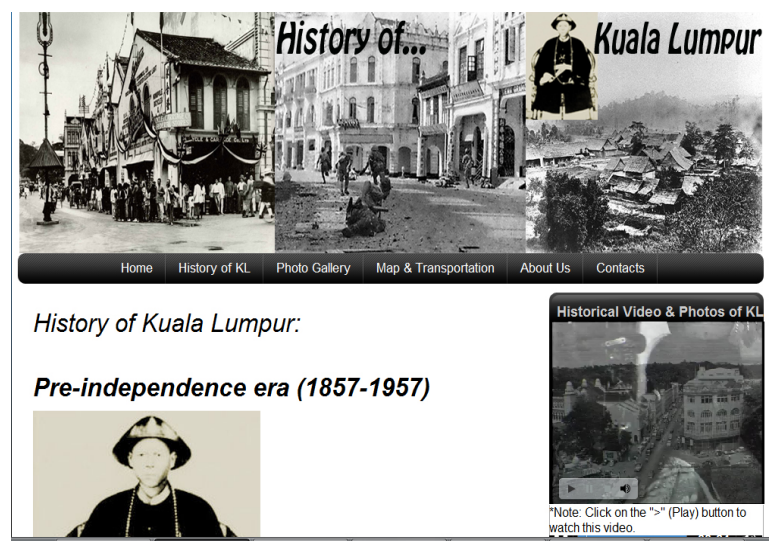

Figure 6: Cultural and heritage site "Sarawak"

\section{Research design}

The research design implemented in this study was a mixed method design. The students were given quantitative and qualitative instruments to gather their reaction as well as their perceptions about learning in this environment. A set of surveys, tests and open-ended questionnaires were administered to gather data for the study.

A set of pre- and post-test questions was given to the students to gauge their learning ability in the multimedia learning object. The purpose of the media-rich environment was to give them some prior knowledge on the characteristics and use of "Digital Sound". The students were given a pre-test at the beginning of the semester. To control for the testing issue of internal validity, the students were not informed of the pre-test and the post-test. It was given as a "pop quiz" type. The post-test was given after they had studied the learning object. The purpose of this testing was to determine their knowledge of the media as well as to know if they were able to recall the subject matter in a cooperative learning environment. The location as well as the person administering the tests remained consistent through out the testing period and they were seated as though it was a real examination setting.

Besides testing, the students were given a set of 5-point Likert scale survey items ( $1=$ Strongly disagree, $2=$ Disagree, $3=$ Undecided, $4=$ Agree and $5=$ Strongly agree). There were 25 questions in the survey that allowed the students to provide feedback on their attitude towards working in this environment. The survey was based on the five components of cooperative learning (Johnson \& Johnson, 1994a), namely:

- Positive interdependence

- Individual accountability

- Promotive interaction

- Interpersonal skills

- Group processing

In addition to these items, another six items were asked to gauge students' attitudes towards using blogs in their learning. The objective for this section of the survey was to determine their ability to reflect on their work done, as well as receiving and giving comments on the work of others, and their overall experience using blogs in their learning. 
The full survey was administered to the students after the submission of their assignment. Besides these Likert survey items, the survey also contained several openended questions that the students were asked to answer. These related to their experience of working as a team and what they felt about doing so. The survey also contained several open-ended questions regarding how they liked or disliked using blogs in their learning.

They were required to complete this survey and since it was also their first time working in such an environment, they were keen to provide feedback on their experience. The students' learning outcomes or the results of their assignments are shown below, while the results of the testing are shown in the following paragraphs, together with the results of the survey and open-ended questions. The illustrative quotations of student feedback given below are from the survey's open-ended questions.

\section{Analysis and results}

\section{Testing results}

Results from the testing (Appendix 1a to 1c) showed that the distribution of the sample was considered normal, while the paired $t$-test showed there was a significant increase in their test scores $(p<0.05)$. This indicates that the students managed to increase their overall mean score after undertaking the multimedia learning object on digital content.

\section{Survey results}

Results from the survey are shown in Appendix 2, which is is listed according to the items related to the six areas mentioned above. The items are broken down in terms of their mean (M) and standard deviation (Std dev) as well as the frequencies of the scale. The items in the tables are shown in descending order of the resulting means. As for the reliability of the survey, the overall reliability is 0.932 while the individual areas (positive inter-dependence, individual accountability, promotive interaction, interpersonal skills, group processing and use of blogs) had Cronbach's alpha higher than 0.6. According to Lim, Khine, Hew, Wong, Divaharan and Lim (2003), a reliability of above 0.6 is deemed adequate. Therefore, this survey is deemed reliable.

Overall the results show that all the survey item means were well above 3.5 which indicate that the students felt positive towards this learning environment. The items relating to positive inter-dependance show that the students depended on their team members, as the means ranged from 3.70 to 4.0 while other areas in the survey such as personal accountability $(\mathrm{m}=3.81$ to 4.00$)$, promotive interaction (3.87 to 4.02$)$, interpersonal skills $(\mathrm{m}=3.83$ to 4.11$)$ and group processing $(\mathrm{m}=3.77$ to 4.06$)$ also showed very high means. These results indicate the students attitudes toward the MICE 2.0 were favourable and they were able to cooperate with their group members. For the items relating to using blogs in their learning process, the means were also high, ranging from 3.62 to 3.75 . It showed that the students were able to reflect and to communicate with their group members and peers by using blogs and posting entries and comments in them.

The following section focuses on the discussion of the results in detail. In addition to the Likert scale survey data, several open-ended questions were given to the students 
to provide feedback on their experiences in working in teams as well as using blogs in their learning. These open-ended questions generally asked them what they liked or disliked about the experience and why. The student feedback is presented as part of the discussion below to provide more evidence about their experiences in this learning environment.

\section{Discussion}

The overall findings indicate that the students were able to work together in groups cooperatively to complete their multimedia projects. As Smith (1995) posits, what makes successful cooperative learning structures differ from weak ones is that the five basic elements - positive inter-dependence, personal accountability, promotive interaction, social skill and group processing - were present and taken into account in the learning process. The findings from the data analysis above confirm that the five components of cooperative learning were present in the learning environment and the students were very much aware of them and used them to work together successfully as a team.

\section{Positive inter-dependence}

Positive inter-dependence suggests that to work together successfully in a cooperative learning environment, members should depend on each other's success for the overall success of the group. Appendix 2 indicates fairly high means (Positive interdependence, $\mathrm{M}=3.70$ to 4.00 ) among the items in this area. Students were active learners and depended on one another for support (Item 4, M=3.70) and problem solving (Item 2, M = 3.83). This feeling of inter-dependency allowed them to feel supported, as they managed to share the workload among their members (Item 3, M = 3.81), and value their teammates' contributions as much as their teammates value their individual contributions (Item $5, \mathrm{M}=3.70$ ). Having a feeling on support and being able to depend on their team made doing this project less stressful (Interpersonal skills, Item 2, M = 3.94) and enjoyable, as many of the students indicated that they enjoyed the success of their team's completing of the assigned project (Item $1, \mathrm{M}=4.00$ ). Some of the comments found when asked about working with their teammates showed support for this finding, for example:

Working with them was very challenging and fun at times. I learned a few skills from them and I wouldn't mind undertaking any other projects with them. (Student 1)

I feel very happy and satisfy when my hard work job had done. I also tried my best to ask my team mate when I face any problem. They are willing to teach me until I understand it. I hope I can learn more applications details about the software that had teach in Digital Media this subject so that I can create my own website in future. (Student 2)

My team mates are responsible and hardworking. They are willing to do the tasks I've assigned for them and send to me on time. I'm glad that I had a chance to work with them. They are some people that we can work with and rely on. (Student 3)

These statements support the positive inter-dependency that the members had with one another. The students were very much aware of the importance of this relationship between members. The blogs also helped them to maintain this inter-dependence as it allowed them to reflect on their individual work (Using blogs - Item 4, M=3.64), while sharing their progress with their mates. The blogs entries provided teams with a way 
for sharing information amongst the group, and receiving feedback through commenting on each other's entries (Using blogs - Item 2, M = 3.70). When asked what they liked about using blogs as a learning tool, many of the students commented that they enjoyed it as they could communicate and share their work with their group. Comments included:

Blog is the method for team mates to communicate. (Student 1)

Can communicate and exchange ideas with group mates. (Student 2)

It made things easier for the team. (Student 3)

\section{Individual accountability}

As for individual accountability, individuals within a team needed to be accountable for their actions and contributions to the team. It gave them a feeling of value as they felt their contributions helped the overall success of the team. Students as individuals knew that their actions would affect the overall outcome of the group's efforts, as the overall means ranged from 3.81 to 4.00 (Appendix 2, Personal accountability). They were able to freely negotiate their ideas and express their thoughts within their group, and were aware of their parts in the team (Item $5, \mathrm{M}=3.81$ ). They were able to contribute their knowledge and skills (Item 3, M = 3.91) to the group and felt that their contributions had a positive effect on the team (Item 1, M = 4.00). Their individual contributions were acknowledged by their teammates while they managed to acknowledge their teammates contributions (Item 4, M = 3.83). This provided a sense of responsibility and assisted them to contribute even more, for the sake of the team. Overall, they felt motivated towards working in teams cooperatively (Item 2, M = 3.96).

The majority of the comments found in the open-ended questions showed that the students enjoyed working cooperatively and knew the value of their personal contributions to the team. Some illustrative comments:

I think I have done my best and also put my own effort to finish my task in this project. I have followed all the instructions given by our team leader and finish the task on time. In addition, I also try to involve all the knowledge learns from tutorial inside our project. (Student 1)

I have been very motivated by working on this project. It helped me to understand what to expect of my team mates the next time and how to conduct myself in a manner that will benefit us all. (Student 2)

I believe I gave my $100 \%$ of commitment and also effort to the team. I hope I lead the team well. I'm glad that I had the chance to be a team leader. (Student 3 )

I think I can put a lot of effort on the part that I've done in the projects. (Student 4)

With the use of blogs, and by having individual entries, each student is able to reflect on his or her work and be aware of the contribution made to the team (Using blogs Item $4, \mathrm{M}=3.64$, and Item $1, \mathrm{M}=3.75$ ). Also, some of the comments stated that having blogs made them improve their work and do their best, because they could share their work in progress with others. Some of the sample comments included:

I like the fact that you can see what others wrote and be able to do better on my work. (Student 1) 
I can interact with my friends, let them know my information. (Student 2)

I like about using blogs, since it quite attracting and can share information to other. (Student 3)

Interesting, can always refer back to it. (Student 4)

\section{Promotive interaction}

In order to work together successfully as a team, each team needs to interact with one another both face to face and by using technology. While working in groups, the groups managed to interact to encourage one another for the success of the team. Having interaction within the group by raising questions with another (Item 2, M = 3.96 ), they were able to pool their knowledge, skills and resources and gain a better understanding of how to do the project (Item 2, M = 3.96), and of the subject matter as a whole (Item 4, M = 3.92), which led to improved performance (Item 3, M = 3.92) in this project. They acknowledged that cooperating as a team helped them understand the course better (Item 1, M = 4.02), which incidentally was the highest scoring item in this area. It provided a way for the members to help one another and to form better relationships with the team and team decision making (Item 5, M=3.87).

In addition to the Likert scale items, students were asked to give feedback about their experiences in working as a team. They understood the importance of team work to understand and complete the task at hand. Some illustrative comments included:

Once we face any problem on doing the project, we get help from each other. This can improve the quality of our project. Besides that, we all also cooperate to each other. Once team leader distribute task to us, we will work hard for it and try to finish it on time. (Student 1)

We helped each other and also put $100 \%$ of commitment into our project. I am happy to have hardworking team mates. Without them, it wouldn't be a success. (Student 2)

My team mates and team leader was so cooperative to each others. We try to share the knowledge we gain from tutorial and help each other in doing this project. (Student 3 )

Also, through the use of the blogs, the groups were able to interact with each other outside the classroom or meeting room, at their own time or whenever a problem or issue arose. Writing entries and commenting on them gave the students a way to voice their fears and problems, and share them with their team members (Using blogs - Item 3, $\mathrm{M}=3.70)$. This is supported by some students' comments in the open-ended questions on their experiences using blogs. These comments indicated that they were able to help each other by posting problems and providing answers through comments. These included:

Able to post information to answer the member's questions and problems. (Student 1)

Can share problems with my group members and friends. (Student 2)

I like because the blog can make me improve in the software skills. (Student 3)

\section{Interpersonal skills}

Students also concurred that working in cooperative teams allowed them to enhance their interpersonal skills. While working in teams, the groups managed to use and 
improve their interpersonal skills. This includes being able to listen to and respect each others ideas. This was the highest rated item in the area as well as the entire survey. Being respectful to the thoughts and ideas of others was highlighted as a significant trait to have in order to work in a team. They also indicated that they were able to share and show their personality to their group members appropriately using their interpersonal skills. This was important for the success of the project and the team, as communicating amongst the team members can help reduce or avoid conflicts. The survey also showed that this item (Item $1, \mathrm{M}=4.11$ ) achieved a very high positive score $(86.8 \%)$.

Many of the students also felt that working in teams made the work less stressful (Item $2, \mathrm{M}=3.94)$, as they were able to depend on each other and communicate with each other effectively, to share ideas and knowledge with their members (Item 4, M =3.85). The students also indicated that they improved their communication and interpersonal skills while working cooperatively on this project in small teams (Item 3, M=3.87).

Having good interpersonal and communications skills was found to be important to many of the students, according to the comments found in the open-ended questions about how they felt they related to their team members. These comments provide further support to the high level of means found in this section of the survey:

To me, the project is quite tough because we need to work with 4 other team members. So, communication is very important. Miscommunications occurred but we overcame it well. (Student 1)

My teammates and team leader is good. We were communicated with others all the time about the projects when we face any problems.(Student 2)

I feel very happy to work together with my all members, team leader and tutorial leader. This is because we can easily communicate what we requested and learn many thing from each of them. We also help each other when facing any problems. (Student 3 )

We can easily communicate with each other and solve any problems when faced it. (Student 4)

The blogs were also used to communicate with each other through commenting. They enjoyed receiving constructive comments from their group members (Using blogs Item $2, M=3.70$ ) as well as their lecturer (Using blogs - Item $5, M=3.62$ ). They indicated that this provided them with a sense of success, as they were able to please their group mates as well as the lecturer with the work they had done so far. It also provided them with a sense of direction and any shortcomings could be adjusted quickly through the comments on the blogs. Moreover, from the comments obtained from the open-ended questions on using blogs, students agreed that using blogs provided them a sense of direction in their work. By using the comments, they were able to make adjustments to their ideas and designs. Some of the sample comments included:

Know others information, can change my thoughts/ideas quickly. (Student 1 )

I like the idea of comments by other peers on my work for adjustment. (Student 2)

I liked the idea of being able to comment/ receive comments on my work for ideas. (Student 3) 


\section{Group processing}

Finally, the students found that working as a team was fruitful and enjoyable. They felt that working as a team helped them learn about cooperating with others properly and effectively. By working in a cooperative learning environment, the results showed that nearly all group felt that they managed to meet their goals (Item $1, M=4.06$ ). This item also achieved a high positive score from $83 \%$ of the students in this course. They felt that working in a team helped enhance their performance, as they managed to reduce misconceptions about doing the project (Item $4, \mathrm{M}=3.79$ ) as well as being able to learn from their mistakes and tolerate the mistakes of others (Item $5, \mathrm{M}=3.77$ ). The majority of students felt that they were able to learn from their team members as well as learning to be patient with one another. It taught them how to learn to tolerate mistakes, both their own as well as their team members. By supporting and encouraging each other in a team, students felt that they worked well as a group. They also enjoyed working in teams (Item $3, \mathrm{M}=3.85$ ) and improved their cooperation with the members of their group (Item 2, M=3.89).

From the comments found in the open-ended questions, many students stated that having a responsible and organised leader who is also being friendly and helpful was crucial, in order to function successfully as a team. Some of the responses included:

My team mates and my team leader are very nice and friendly. (Student 1)

My leader is a nice and responsible leader. From earlier, she had assigned the jobs to us so that we can settle this assignment in a short period of time. She also teach and support us when we facing problems. She is a nice and friendly leader that lead our group members so well. My group members are also very kind and responsible. When face any problems, they willing to teach me and help me settle the problem so that our work can proceed faster. (Student 2)

My tutorial group leader is an international student, but he is also very responsible. He tried hard to mix with us and ask our opinions when choosing the topics for each groups. He worked hard to search more information about Malaysia tourism for us as out each group topics. We can clearly see that he really work very hard to be a good tutorial group leader. (Student 3)

Overall, in the context of group processing, blogs provided them with a learning space to discuss and work together as a group. The results indicated that the student groups found using blogs a good learning experience (Using blogs - Item 6, M=3.62), as it allowed them to keep in constant communication with each other, able to know how each group member was progressing in their part of the project. This was also true when asking the students about their overall experience using blogs. Many of them enjoyed using blogs as it was their first experience doing so, while many found it interesting and informal. Illustrative comments included:

It was the first time but very enjoyable and fun. (Student 1)

It was my first time to use the blog and I really love it. (Student 2)

Have fun on it because it helped me learned in an informal manner. (Student 3)

\section{Negative blogging experiences}

However, there was a minority of students who felt unsure about whether the blogs were helpful in their learning. They indicated that they were undecided on most of the 
items in this part of the survey, especially items $4(41.5 \%), 5(28.3 \%)$ and $6(35.8 \%)$. This was possibly due to their feeling frustrated in using blogs, as well as their inability to use the tools effectively. This finding was confirmed from the negative feedback received from some of the open-ended questions. Some students did not like blogs because they found it complicated and too much work. Some of the student comments included:

Too much work to be done. First it's assignment the blogs tiring (Student 1)

Didn't know how to use it so had a hard time. (Student 2)

Dislike as it's tedious to be reporting on a blog. (Student 3)

Some of the students felt unsure about whether using blogs improved their learning process. This could be due to their first experience in using blogs and not knowing if it helped their learning. This was also evident from some of the students' comments on their experiences using blogs as a learning tool, including:

I hate blogs. First time. (Student 1)

I dislike about the blog because there were many steps to use the blog. (Student 2)

I do not like everyone to access and see my blog including project process. (Student 3)

However, overall the majority of students managed to use blogs as a learning tool and as part of their cooperative learning process. This too was indicated by their numerous comments on experiences with blogging as a learning tool.

I like the consistent updates. It makes me feel engaged and focused in my project/

studies. (Student 1)

It is a good learning method. (Student 2)

Good experience. (Student 3)

\section{Conclusion}

In this study, the findings show that students working in a cooperative learning environment enhance their active learning processes. They improved their abilities as indicated by the significant improvements between their pre-test and post-test scores in the multimedia learning environment. Also, by working in small teams, students were able to improve their teamwork skills, interpersonal skills, and their understanding of the role of individual responsibility within a team. They learnt that respect, communication, sharing and tolerance were important facets of teamwork and crucial for the success of the project. As Zakaria and Iksan (2007) suggested, learners should understand the value of cooperation and mutual respect, coupled with good communication skills, in order to become a contributing member of a society. Using blogs as a reflective and communication tool assisted in their team learning and group processing, as they were able to update each other on their individual progress and give constructive comments. This finding is similar to findings by Deitering and Huston (2004), who reported that blogs enhance student interaction. Through integrating the use of multimedia tools, blogs and Web 2.0 tools, as well as components of cooperative learning, the learning experience that the students 
encounter helps them acquire understanding and skills for their work life, including lifelong learning skills necessary in today's ever fast and ever changing environment.

\section{Acknowledgment}

We would like to thank TM R\&D Berhad (Malaysia) for funding this project and their support and commitment to our research. The authors would also like to thank the students of Multimedia University for participating in this research.

\section{References}

Allen, M. \& Long, J. (2009). Learning as knowledge networking: Conceptual foundations for revised uses of the Internet in higher education. In Proceedings of the World Congress on Engineering and Computer Science 2009, Vol I, 20-22 October, San Francisco. http: / / www.iaeng.org/ publication/WCECS2009/WCECS2009_pp652-657.pdf

Archer-Kath, J., Johnson, D. W. \& Johnson, R. T. (1994). Individual versus group feedback in cooperative group. The Journal of Social Psychology, 134(5), 681-694. http: / / dx.doi.org/10.1080/00224545.1994.9922999

Bruner, J. S. (1985). Models of the learner. Educational Researcher, 14(6), 5-8. http: / / www.jstor.org/ stable/1174162

Coutinho, C. P. (2007). Infusing technology in pre service teacher education programs in Portugal: An experience with weblogs. In R. Craslen et al. (Eds.), Proceedings of the 18th International Conference of the Society for Information Technology and Teacher Education (pp. 20272034). Chesapeake: SITE. http:/ / www.editlib.org/p/24975

Dahley, A. M. (1994). Cooperative learning classroom research. http: / / alumni.media.mit.edu / andyd / mindset/design/clc_rsch.html

Deitering, A. M. \& Huston, S. (2004). Weblogs and the "middle space" for learning. Academic Exchange Quarterly, 8(4), 273-278. http:/ / www.rapidintellect.com/ AEQweb/5mar2879z4.htm

Dewey, J. (1896). The reflex arc concept of psychology. Psychology Review, 3, 357-370.

Farmer, B., Yue, A. \& Brooks, C. (2008). Using blogging for higher order learning in large cohort university teaching: A case study. Australasian Journal of Educational Technology, 24(2), 123136. http:/ / www.ascilite.org.au/ajet/ ajet24/farmer.html

Fiedler, S. (2003). Personal webpublishing as a refective conversational tool for self-organized learning. In T. N. Burg (Ed.), BlogTalks. (pp. 190-216). Vienna, Austria.

Gagne, R., Briggs, L. \& Wager, W. (1992). Principles of instructional design. Fort Worth, TX: Harcourt Brace Jovanovich.

Gaikwad, P. (1996). Cooperative learning: Setting the stage for faith and learning in the classroom. Institute for Christian Teaching, Silver Spring, MD (viewed 29 Aug 2011) http: / / www.aiias.edu/ict/vol_18/18cc_039-062.htm

Garfield, J. (1995). How students learn statistics. International Statistical Review, 63, 25-34.

Gerlach, J. M. (1994). Is this collaboration? In K. Bosworth \& S. J. Hamilton (Eds.), Collaborative learning: Underlying processes and effective technique. San Francisco: Jossey-Bass.

Goh. J. W. P., Quek, C. J., \& Lee, O. K. (2010). An investigation of students' perceptions of learning benefits of weblogs in an East Asian context: A Rasch analysis. Educational Technology \& Society, 13(2), 90-101. http:/ / www.ifets.info/journals/13_2/8.pdf 
Huang, T.-C., Huang, Y.-M. \& Yu, F.-Y. (2011). Cooperative weblog learning in higher education: Its facilitating effects on social interaction, time lag, and cognitive load. Educational Technology $\mathcal{E}$ Society, 14(1), 95-106. http://www.ifets.info/journals/14_1/9.pdf

Jacobs, G. \& Hannah, D. (2004). Combining cooperative learning with reading aloud by teachers. International Journal of English Studies, 4(1), 97-118. [preprint verified 12 Jul 2012] http:/ / www.georgejacobs.net/Articles/CL_and_Reading_Aloud.htm

Jensen, M., Johnson, D. W. \& Johnson, R. T. (2002). Impact of positive interdependence during electronic quizzes on discourse and achievement. The Journal of Educational Research, 95(3), 161-167. http: / / www.jstor.org/ discover/10.2307/27542374?

Johnson D. W. \& Johnson R. T. (1989). Cooperation and competition: Theory and research. Edina, MN: Interaction Book Company.

Johnson, D. W., Johnson, R. T. \& Smith, K. (1991). Cooperative learning: Increasing college faculty instructional productivity. ASHE-ERIC Higher Education Report No. 4, Washington, DC: The George Washington University. [verified 12 Jul 2012; 4.0 MB] http: / / www.eric.ed.gov/ ERICWebPortal / contentdelivery / servlet/ ERICServlet?accno=ED343465

Johnson, D. W., Johnson, R. T. \& Holubec, E. J. (1994). Cooperative learning in the classroom. VA: Association for Supervision and Curriculum Development. http: / / www.ascd.org/publications/books/194224.aspx

Johnson D. W. \& Johnson, R. T. (1994a). Joining together: Group theory and group skills (5th ed.) Boston: Allyne \& Bacon.

Johnson, R. T. \& Johnson, D. W. (1994b). An overview of cooperative learning. In J. Thousand, A. Villa \& A. Nevin (Eds.), Creativity and collaborative learning. Brookes Press, Baltimore. [verified 12 Jul 2012] http: / / clearspecs.com/joomla15/downloads/ClearSpecs69V01 _Overview\%20of\%20Cooperative \%20Learning.pdf

Johnson, D. W., Johnson, R. T. \& Smith, K. (1998). Active learning: Cooperation in the college classroom. Edina, MN: Interaction Book Company.

Johnson, D. W. \& Johnson, R. T. (1999). Learning together and alone: Cooperative, competitive and individualistic learning (5th ed.). Boston: Allyn \& Bacon.

Johnson, D. W. \& Johnson, F. P. (2003). Joining together: Group theory and group skills (8th Ed). Needham Heights, MA: Allyn \& Bacon.

Jonassen, D. H. (1994). Thinking technology: Towards a constructivist design method. Educational Technology, April, pp. 34-37.

Krajcik, J. S., Blumenfeld, P. C., Marx, R. W., Bass, K. M. \& Fredricks, J. (1998). Inquiry in projectbased science classrooms: Initial attempts by middle school students. Journal of the Learning Sciences, 7(3/4), 313-350. http:/ / dx.doi.org/10.1080/10508406.1998.9672057

Lim C. P., Khine, M. S., Hew, T., Wong, P., Divaharan, S. \& Lim, B. (2003). Exploring critical aspects of information technologies integration in Singapore schools. Australian Journal of Educational Technology, 19(1), 1-24. http:/ / www.ascilite.org.au/ajet/ajet19/lim.html

Makri, K. \& Kynigos, C. (2007). The role of blogs in studying the discourse and social practices of mathematics teachers. Educational Technology \& Society, 10(1), 73-84. http: / / www.ifets.info/journals/10_1/8.pdf

McConnell, D. (2000). Implementing computer supported cooperative learning (2nd ed). London: Kogan Page. 
McNeese, M. D. (2000). Socio-cognitive factors in the acquisition and transfer of knowledge. Cognition, Technology \& Work, 2, 164-177. [verified 12 Jul 2012] http: / / www.dtic.mil/ cgibin/GetTRDoc?AD=ADA476981

McWhaw, K., Schnackenberg, H., Sclater, J. \& Abrami, P. C. (2003). From co-operation to collaboration: Helping students become collaborative learners. In R. M. Giles \& A. F. Ashman (Eds), Co-operative learning. London: RoutledgeFalmer.

Millis, B. J. (2002). Enhancing learning - and more! - through cooperative learning. Idea Paper \#38. The Idea Centre, 211 South Seth Child Road Manhattan. http: / / www.theideacenter.org/sites/default/ files / IDEA_Paper_38.pdf

Neo, M., Neo, T. K. \& Rafi, M. E. (2004). Designing interactive multimedia curricula to enhance teaching and learning in the Malaysian classroom - From teacher-led to student-centred experiences. International Journal of Instructional Media, 34(1).

Papert, S. (1980). Mindstorms: Children, computers, and powerful ideas. New York: Basic Books.

Piaget, J. (1952). The origins of intelligence in children. New York: International Universities Press.

Saddler, B. (2008). Cooperative learning: A process for effective inclusion. [viewed 15 Aug 2011, verified 12 Jul 2012] https:/ / www.kdp.org/teachingresources/pdf/Saddler.pdf

Smith, K. (1995). Cooperative learning: Effective teamwork for engineering classrooms. Proceedings, Frontiers in Education Conference, 1995. http: / / ieeexplore.ieee.org/xpl/login.jsp?tp=\&arnumber $=483059$

Stanton, P. \& Fairfax, D. (2007). Establishing individual accountability for learning in an examless, group project course. Proceedings of the ASEE Mid-Atlantic Section Fall 2007 Conference, Temple University, pp. 3-12. http: / / www.asee.org/documents/ sections / middleatlantic/2007/ 04-Establishing-Individual-Accountability.pdf

Stevens, R. J., \& Slavin, R. E. (1995). The cooperative elementary school: Effects on students' achievement, attitudes, and social relations. American Educational Research Journal, 32, 321-351. http:/ / www.eric.ed.gov/ERICWebPortal/ contentdelivery/ servlet/ERICServlet?accno=ED349098

Tanner, K., Chatman, L. S. \& Allen, D. (2003). Approaches to cell biology teaching: Cooperative learning in the science classroom - beyond students working in groups. Cell Biology Education, 2, 1-5. http: / / www.lifescied.org/ content/2/1/1.full.pdf + html

Teoh, B. S. P \& Neo, T. K. (2007). Interactive multimedia learning: Students' attitudes and learning impact in an animation course. The Turkish Online Journal of Educational Technology, 6(4). http: / / www.tojet.net/articles/v6i4/643.pdf

Williams, J. B. \& Jacobs, J. (2004). Exploring the use of blogs as learning spaces in the higher education sector. Australasian Journal of Educational Technology, 20(2), 232-247. http: / / www.ascilite.org.au/ajet/ajet20/ williams.html

Vygotsky, L. S. (1978). Mind in society. Cambridge, MA: Harvard University Press.

Zakaria, E. \& Iksan, Z. (2007). Promoting cooperative learning in science and mathematics education: A Malaysian perspective. Eurasia Journal of Mathematics, Science E Technology Education, 3(1), 35-39. http: / / www.eric.ed.gov / ERICWebPortal/contentdelivery/ servlet / ERICServlet?accno=ED496240

Zimbardo, P. G., Butler, L. D. \& Wolfe, V. A. (2003). Cooperative college examinations: More gain, less pain when students share information and grades. Journal of Experimental Education, 71(2), 101-126. http: / / www.jstor.org/ discover/10.2307/20152702? 


\section{Appendix 1a-1c: Test of normality and paired t-test}

a. Tests of normality

\begin{tabular}{|l|c|c|c|}
\hline \multirow{2}{*}{} & \multicolumn{3}{|c|}{ Shapiro-Wilk } \\
\cline { 2 - 4 } & Statistic & $\mathrm{df}$ & Sig. \\
\hline Difference score & .975 & 53 & .330 \\
\hline
\end{tabular}

b. Paired samples statistics

\begin{tabular}{|l|l|c|c|c|c|}
\hline \multicolumn{2}{|c|}{} & Mean & $\mathrm{N}$ & Std. deviation & Std. error mean \\
\hline \multirow{2}{*}{ Pair 1 } & Pretest score & 9.94 & 53 & 3.060 & .420 \\
\cline { 2 - 6 } & Posttest score & 12.70 & 53 & 3.434 & .472 \\
\hline
\end{tabular}

c. Paired samples test

\begin{tabular}{|c|c|c|c|c|c|c|c|c|c|}
\hline & \multicolumn{5}{|c|}{ Paired differences } & \multirow{3}{*}{$\mathrm{t}$} & \multirow{3}{*}{$\mathrm{df}$} & \multirow{3}{*}{ Sig. (2-tailed) } \\
\hline & & \multirow[t]{2}{*}{ Mean } & \multirow{2}{*}{$\begin{array}{l}\text { Std. } \\
\text { dev. }\end{array}$} & \multirow{2}{*}{$\begin{array}{c}\text { Std. error } \\
\text { mean }\end{array}$} & \multicolumn{2}{|c|}{$\begin{array}{l}95 \% \text { confidence } \\
\text { interval of the diff. }\end{array}$} & & & \\
\hline & & & & & Lower & Upper & & & \\
\hline $\begin{array}{c}\text { Pair } \\
1\end{array}$ & $\begin{array}{l}\text { Pretest score - } \\
\text { Posttest score }\end{array}$ & -2.755 & 3.316 & .455 & -3.669 & -1.841 & -6.048 & 52 & .000 \\
\hline
\end{tabular}

\section{Appendix 2: Results of the survey}

\begin{tabular}{|c|c|c|c|c|c|c|c|c|}
\hline \multicolumn{9}{|c|}{ Positive inter-dependence } \\
\hline No. & Survey & $\begin{array}{l}\text { SD } \\
\mathrm{f}(\%)\end{array}$ & $\begin{array}{l}\mathrm{D} \\
\mathrm{f}(\%)\end{array}$ & $\begin{array}{c}\mathrm{U} \\
\mathrm{f}(\%)\end{array}$ & $\begin{array}{c}\mathrm{A} \\
\mathrm{f}(\%)\end{array}$ & $\begin{array}{l}\text { SA } \\
\mathrm{f}(\%)\end{array}$ & $\begin{array}{l}\text { Mean } \\
\text { (M) }\end{array}$ & $\begin{array}{l}\text { Std } \\
\text { dev }\end{array}$ \\
\hline 1 & $\begin{array}{l}\text { I felt happy about the success of the } \\
\text { group as a whole }\end{array}$ & $\begin{array}{c}0 \\
(0.0)\end{array}$ & $\begin{array}{c}1 \\
(1.9)\end{array}$ & $\begin{array}{c}14 \\
(26.4) \\
\end{array}$ & $\begin{array}{c}22 \\
(41.5)\end{array}$ & $\begin{array}{c}16 \\
(30.2) \\
\end{array}$ & 4.00 & .809 \\
\hline 2 & $\begin{array}{l}\text { We assisted each other while } \\
\text { solving problems during the } \\
\text { multimedia project }\end{array}$ & $\begin{array}{c}0 \\
(0.0)\end{array}$ & $\begin{array}{c}1 \\
(1.9)\end{array}$ & $\begin{array}{c}13 \\
(24.5)\end{array}$ & $\begin{array}{c}33 \\
(62.3)\end{array}$ & $\begin{array}{c}6 \\
(11.3)\end{array}$ & 3.83 & .643 \\
\hline 3 & $\begin{array}{l}\text { I was able to share the load of the } \\
\text { work with my group members }\end{array}$ & $\begin{array}{c}0 \\
(0.0)\end{array}$ & $\begin{array}{c}1 \\
(1.9)\end{array}$ & $\begin{array}{c}14 \\
(26.4)\end{array}$ & $\begin{array}{c}32 \\
(60.4)\end{array}$ & $\begin{array}{c}6 \\
(11.3)\end{array}$ & 3.81 & .652 \\
\hline 4 & $\begin{array}{l}\text { I managed to depend on my } \\
\text { members as they depend on me }\end{array}$ & $\begin{array}{c}0 \\
(0.0) \\
\end{array}$ & $\begin{array}{c}1 \\
(1.9)\end{array}$ & $\begin{array}{c}18 \\
(34) \\
\end{array}$ & $\begin{array}{c}30 \\
(56.6)\end{array}$ & $\begin{array}{c}4 \\
(7.5) \\
\end{array}$ & 3.70 & .638 \\
\hline 5 & $\begin{array}{l}\text { I was able to value the contributions } \\
\text { of the other members of the group }\end{array}$ & $\begin{array}{c}0 \\
(0.0) \\
\end{array}$ & $\begin{array}{c}1 \\
(1.9)\end{array}$ & $\begin{array}{c}18 \\
(34)\end{array}$ & $\begin{array}{c}30 \\
(56.6)\end{array}$ & $\begin{array}{c}4 \\
(7.5) \\
\end{array}$ & 3.70 & .638 \\
\hline $\mathrm{N}=53$ & Cronbach's alpha $=0.729$ & & & & & & & \\
\hline \multicolumn{9}{|c|}{ Personal accountability } \\
\hline No. & Survey & $\begin{array}{l}\text { SD } \\
\mathrm{f}(\%)\end{array}$ & $\begin{array}{c}\mathrm{D} \\
\mathrm{f}(\%)\end{array}$ & $\mathrm{U}(\%)$ & $\begin{array}{c}\mathrm{A} \\
\mathrm{f}(\%)\end{array}$ & $\begin{array}{l}\text { SA } \\
\mathrm{f}(\%)\end{array}$ & $\begin{array}{l}\text { Mean } \\
(\mathrm{M})\end{array}$ & $\begin{array}{l}\text { Std } \\
\text { dev }\end{array}$ \\
\hline 1 & $\begin{array}{l}\text { I made positive contributions to the } \\
\text { group }\end{array}$ & $\begin{array}{c}0 \\
(0.0)\end{array}$ & $\begin{array}{c}0 \\
(0.0)\end{array}$ & $\begin{array}{c}12 \\
(22.6)\end{array}$ & $\begin{array}{c}29 \\
(54.7)\end{array}$ & $\begin{array}{c}12 \\
(22.6)\end{array}$ & 4.00 & .679 \\
\hline 2 & $\begin{array}{l}\text { I was able to find working } \\
\text { cooperatively very motivating }\end{array}$ & $\begin{array}{c}0 \\
(0.0)\end{array}$ & $\begin{array}{c}1 \\
(1.9)\end{array}$ & $\begin{array}{c}11 \\
(20.8)\end{array}$ & $\begin{array}{c}30 \\
(56.6)\end{array}$ & $\begin{array}{c}11 \\
(20.8)\end{array}$ & 3.96 & .706 \\
\hline 3 & $\begin{array}{l}\text { I managed to contribute my } \\
\text { knowledge to the team }\end{array}$ & $\begin{array}{c}0 \\
(0.0) \\
\end{array}$ & $\begin{array}{c}0 \\
(0.0) \\
\end{array}$ & $\begin{array}{c}13 \\
(24.5)\end{array}$ & $\begin{array}{c}32 \\
(60.4)\end{array}$ & $\begin{array}{c}8 \\
(15.1)\end{array}$ & 3.91 & .628 \\
\hline 4 & $\begin{array}{l}\text { I was able to share my knowledge, } \\
\text { and take into account the know- } \\
\text { ledge of the other group members }\end{array}$ & $\begin{array}{c}0 \\
(0.0)\end{array}$ & $\begin{array}{c}0 \\
(0.0)\end{array}$ & $\begin{array}{c}15 \\
(28.3)\end{array}$ & $\begin{array}{c}32 \\
(60.4)\end{array}$ & $\begin{array}{c}6 \\
(11.3)\end{array}$ & 3.83 & .612 \\
\hline 5 & $\begin{array}{l}\text { I was aware exactly of what my } \\
\text { part in the group was }\end{array}$ & $\begin{array}{c}0 \\
(0.0)\end{array}$ & $\begin{array}{c}1 \\
(1.9)\end{array}$ & $\begin{array}{c}13 \\
(24.5)\end{array}$ & $\begin{array}{c}34 \\
(64.2)\end{array}$ & $\begin{array}{c}5 \\
(9.4)\end{array}$ & 3.81 & .622 \\
\hline \multicolumn{9}{|c|}{$\mathrm{N}=53$, Cronbach's alpha $=0.814$} \\
\hline
\end{tabular}




\begin{tabular}{|c|c|c|c|c|c|c|c|c|}
\hline \multicolumn{9}{|c|}{ Promotive interaction } \\
\hline No. & Survey & $\begin{array}{c}\mathrm{SD} \\
\mathrm{f}(\%)\end{array}$ & $\underset{\mathrm{f}(\%)}{\mathrm{D}}$ & $\underset{\mathrm{f}(\%)}{\mathrm{U}}$ & $\begin{array}{c}\mathrm{A} \\
\mathrm{f}(\%)\end{array}$ & $\begin{array}{l}\text { SA } \\
\mathrm{f}(\%)\end{array}$ & $\begin{array}{l}\text { Mean } \\
(\mathrm{M})\end{array}$ & $\begin{array}{l}\text { Std } \\
\text { dev }\end{array}$ \\
\hline 1 & $\begin{array}{l}\text { Cooperating in a group promoted } \\
\text { better understanding of the subject }\end{array}$ & $\begin{array}{c}0 \\
(0.0)\end{array}$ & $\begin{array}{c}0 \\
(0.0)\end{array}$ & $\begin{array}{c}10 \\
(18.9)\end{array}$ & $\begin{array}{c}32 \\
(60.4)\end{array}$ & $\begin{array}{c}11 \\
(20.8)\end{array}$ & 4.02 & .635 \\
\hline 2 & $\begin{array}{l}\text { By raising questions among group } \\
\text { members help improved the under- } \\
\text { standing of the multimedia project }\end{array}$ & $\begin{array}{c}0 \\
(0.0)\end{array}$ & $\begin{array}{c}1 \\
(1.9)\end{array}$ & $\begin{array}{c}7 \\
(13.2)\end{array}$ & $\begin{array}{c}38 \\
(71.7)\end{array}$ & $\begin{array}{c}7 \\
(13.2)\end{array}$ & 3.96 & .587 \\
\hline 3 & $\begin{array}{l}\text { The interaction with my peers } \\
\text { helped improve my performance }\end{array}$ & $\begin{array}{c}0 \\
(0.0)\end{array}$ & $\begin{array}{c}2 \\
(3.8)\end{array}$ & $\begin{array}{c}11 \\
(20.8)\end{array}$ & $\begin{array}{c}29 \\
(54.7) \\
\end{array}$ & $\begin{array}{c}11 \\
(20.8)\end{array}$ & 3.92 & .756 \\
\hline 4 & $\begin{array}{l}\text { Interaction among group members } \\
\text { helped me to obtain a deeper } \\
\text { understanding of the subject }\end{array}$ & $\begin{array}{c}0 \\
(0.0)\end{array}$ & $\begin{array}{c}1 \\
(1.9)\end{array}$ & $\begin{array}{c}6 \\
(11.3)\end{array}$ & $\begin{array}{c}43 \\
(81.1)\end{array}$ & $\begin{array}{c}3 \\
(5.7)\end{array}$ & 3.91 & .491 \\
\hline 5 & $\begin{array}{l}\text { We made effective decisions } \\
\text { together as a group }\end{array}$ & $\begin{array}{c}0 \\
(0.0) \\
\end{array}$ & $\begin{array}{c}3 \\
(5.7) \\
\end{array}$ & $\begin{array}{c}10 \\
(18.9)\end{array}$ & $\begin{array}{c}31 \\
(58.5)\end{array}$ & $\begin{array}{c}9 \\
(17)\end{array}$ & 3.87 & .761 \\
\hline \multirow{2}{*}{\multicolumn{9}{|c|}{$\mathrm{N}=53$, Cronbach's alpha $=0.753$}} \\
\hline & & & & & & & & \\
\hline No. & Survey & $\begin{array}{l}\mathrm{SD} \\
\mathrm{f}(\%)\end{array}$ & $\begin{array}{c}\mathrm{D} \\
\mathrm{f}(\%)\end{array}$ & $\begin{array}{c}\mathrm{U} \\
\mathrm{f}(\%)\end{array}$ & $\begin{array}{c}\mathrm{A} \\
\mathrm{f}(\%)\end{array}$ & $\begin{array}{l}\text { SA } \\
\mathrm{f}(\%)\end{array}$ & $\begin{array}{l}\text { Mean } \\
(\mathrm{M})\end{array}$ & $\begin{array}{l}\text { Std } \\
\text { dev }\end{array}$ \\
\hline 1 & $\begin{array}{l}\text { I was able to listen to and respect } \\
\text { the ideas of others }\end{array}$ & $\begin{array}{c}0 \\
(0.0)\end{array}$ & $\begin{array}{c}0 \\
(0.0)\end{array}$ & $\begin{array}{c}7 \\
(13.2)\end{array}$ & $\begin{array}{c}33 \\
(62.3)\end{array}$ & $\begin{array}{c}13 \\
(24.5)\end{array}$ & 4.11 & .610 \\
\hline 2 & $\begin{array}{l}\text { Working cooperatively with my } \\
\text { group is less stressful }\end{array}$ & $\begin{array}{c}0 \\
(0.0)\end{array}$ & $\begin{array}{c}3 \\
(5.7)\end{array}$ & $\begin{array}{c}7 \\
(13.2)\end{array}$ & $\begin{array}{c}33 \\
(62.3)\end{array}$ & $\begin{array}{c}10 \\
(18.9)\end{array}$ & 3.94 & .745 \\
\hline 3 & $\begin{array}{l}\text { Through working cooperatively in a } \\
\text { group helped improve my } \\
\text { communication skills }\end{array}$ & $\begin{array}{c}0 \\
(0.0)\end{array}$ & $\begin{array}{c}2 \\
(3.8)\end{array}$ & $\begin{array}{c}10 \\
(18.9)\end{array}$ & $\begin{array}{c}34 \\
(64.2)\end{array}$ & $\begin{array}{c}7 \\
(13.2)\end{array}$ & 3.87 & .680 \\
\hline 4 & $\begin{array}{l}\text { I was able to share my ideas, } \\
\text { personality, workload, and so on } \\
\text { with the rest of my group members }\end{array}$ & $\begin{array}{c}0 \\
(0.0)\end{array}$ & $\begin{array}{c}1 \\
(1.9)\end{array}$ & $\begin{array}{c}12 \\
(22.6)\end{array}$ & $\begin{array}{c}34 \\
(64.2)\end{array}$ & $\begin{array}{c}6 \\
(11.3)\end{array}$ & 3.85 & .632 \\
\hline 5 & $\begin{array}{l}\text { I had the opportunity to commun- } \\
\text { icate with my group members }\end{array}$ & $\begin{array}{c}0 \\
(0.0)\end{array}$ & $\begin{array}{c}1 \\
(1.9)\end{array}$ & $\begin{array}{c}15 \\
(28.3)\end{array}$ & $\begin{array}{c}29 \\
(54.7)\end{array}$ & $\begin{array}{c}8 \\
(15.1) \\
\end{array}$ & 3.83 & .700 \\
\hline \multicolumn{9}{|c|}{$\mathrm{N}=53$, Cronbach's alpha $=0.788$} \\
\hline \multicolumn{9}{|c|}{ Group processing } \\
\hline No. & Survey & $\begin{array}{c}\mathrm{SD} \\
\mathrm{f}(\%)\end{array}$ & $\begin{array}{c}\mathrm{D} \\
\mathrm{f}(\%)\end{array}$ & $\begin{array}{c}\mathrm{U} \\
\mathrm{f}(\%)\end{array}$ & $\begin{array}{c}\mathrm{A} \\
\mathrm{f}(\%)\end{array}$ & $\begin{array}{c}\text { SA } \\
\mathrm{f}(\%)\end{array}$ & $\begin{array}{l}\text { Mean } \\
(\mathrm{M})\end{array}$ & $\begin{array}{l}\text { Std } \\
\text { dev }\end{array}$ \\
\hline 1 & $\begin{array}{l}\text { My group managed to achieve our } \\
\text { group goals }\end{array}$ & $\begin{array}{c}0 \\
(0.0)\end{array}$ & $\begin{array}{c}1 \\
(1.9)\end{array}$ & $\begin{array}{c}8 \\
(15.1)\end{array}$ & $\begin{array}{c}31 \\
(58.5)\end{array}$ & $\begin{array}{c}13 \\
(24.5)\end{array}$ & 4.06 & .691 \\
\hline 2 & $\begin{array}{l}\text { Working in group help enhanced } \\
\text { cooperation among the group } \\
\text { members }\end{array}$ & $\begin{array}{c}0 \\
(0.0)\end{array}$ & $\begin{array}{c}2 \\
(3.8)\end{array}$ & $\begin{array}{c}10 \\
(18.9)\end{array}$ & $\begin{array}{c}33 \\
(62.3)\end{array}$ & $\begin{array}{c}8 \\
(15.1)\end{array}$ & 3.89 & .698 \\
\hline 3 & $\begin{array}{l}\text { I enjoyed working with my group } \\
\text { members as a team }\end{array}$ & $\begin{array}{c}0 \\
(0.0) \\
\end{array}$ & $\begin{array}{c}2 \\
(3.8) \\
\end{array}$ & $\begin{array}{c}16 \\
(30.2)\end{array}$ & $\begin{array}{c}23 \\
(43.4) \\
\end{array}$ & $\begin{array}{c}12 \\
(22.6)\end{array}$ & 3.85 & .818 \\
\hline 4 & $\begin{array}{l}\text { Working cooperatively helped to } \\
\text { reduce my misconceptions about } \\
\text { the topic }\end{array}$ & $\begin{array}{c}0 \\
(0.0)\end{array}$ & $\begin{array}{c}2 \\
(3.8)\end{array}$ & $\begin{array}{c}12 \\
(22.6)\end{array}$ & $\begin{array}{c}34 \\
(64.2)\end{array}$ & $\begin{array}{c}5 \\
(9.4)\end{array}$ & 3.79 & .661 \\
\hline 5 & $\begin{array}{l}\text { I was able to learn through my } \\
\text { mistake and be tolerant with my } \\
\text { group members }\end{array}$ & $\begin{array}{c}0 \\
(0.0)\end{array}$ & $\begin{array}{c}1 \\
(1.9)\end{array}$ & $\begin{array}{c}13 \\
(24.5)\end{array}$ & $\begin{array}{c}36 \\
(67.9)\end{array}$ & $\begin{array}{c}3 \\
(5.7)\end{array}$ & 3.77 & .577 \\
\hline \multicolumn{9}{|c|}{$\mathrm{N}=53$, Cronbach's alpha $=0.873$} \\
\hline \multicolumn{9}{|c|}{ Using blogs } \\
\hline No. & Survey & $\begin{array}{l}\mathrm{SD} \\
\mathrm{f}(\%)\end{array}$ & $\begin{array}{c}\mathrm{D} \\
\mathrm{f}(\%)\end{array}$ & $\begin{array}{c}\mathrm{U} \\
\mathrm{f}(\%)\end{array}$ & $\begin{array}{c}\mathrm{A} \\
\mathrm{f}(\%)\end{array}$ & $\begin{array}{c}\text { SA } \\
\mathrm{f}(\%)\end{array}$ & $\begin{array}{c}\text { Mean } \\
(\mathrm{M})\end{array}$ & $\begin{array}{l}\text { Std } \\
\text { dev }\end{array}$ \\
\hline 1 & $\begin{array}{l}\text { I was able to gain a better insight on } \\
\text { the assignment by looking at other } \\
\text { students work. }\end{array}$ & $\begin{array}{c}0 \\
(0.0)\end{array}$ & $\begin{array}{c}2 \\
(3.8)\end{array}$ & $\begin{array}{c}15 \\
(28.3)\end{array}$ & $\begin{array}{c}30 \\
(56.6)\end{array}$ & $\begin{array}{c}6 \\
(11.3)\end{array}$ & 3.75 & .705 \\
\hline
\end{tabular}




\begin{tabular}{|c|l|c|c|c|c|c|c|c|}
\hline 2 & $\begin{array}{l}\text { I enjoyed people commenting on } \\
\text { my work and giving me advice. }\end{array}$ & $\begin{array}{c}1 \\
(1.9)\end{array}$ & $\begin{array}{c}3 \\
(5.7)\end{array}$ & $\begin{array}{c}10 \\
(18.9)\end{array}$ & $\begin{array}{c}36 \\
(67.9)\end{array}$ & $\begin{array}{c}3 \\
(5.7)\end{array}$ & 3.70 & .749 \\
\hline 3 & $\begin{array}{l}\text { The comments on my work were } \\
\text { helpful to improve my learning } \\
\text { process }\end{array}$ & $\begin{array}{c}0 \\
(0.0)\end{array}$ & $\begin{array}{c}5 \\
(9.4)\end{array}$ & $\begin{array}{c}12 \\
(22.6)\end{array}$ & $\begin{array}{c}30 \\
(56.6)\end{array}$ & $\begin{array}{c}6 \\
(11.3)\end{array}$ & 3.70 & .799 \\
\hline 4 & $\begin{array}{l}\text { I was able to reflect my understand- } \\
\text { ing of my assignments through rea- } \\
\text { ding my entries written in the blogs }\end{array}$ & $\begin{array}{c}1 \\
(1.9)\end{array}$ & $\begin{array}{c}0 \\
(0.0)\end{array}$ & $\begin{array}{c}22 \\
(41.5)\end{array}$ & $\begin{array}{c}24 \\
(45.3)\end{array}$ & $\begin{array}{c}6 \\
(11.3)\end{array}$ & 3.64 & .762 \\
\hline 5 & $\begin{array}{l}\text { The comments by the teacher were } \\
\text { helpful. }\end{array}$ & 0 & 4 & 15 & 31 & 3 & 3.62 & .713 \\
$(0.0)$ & $(7.5)$ & $(28.3)$ & $(58.5)$ & $(5.7)$ & 3 \\
\hline 6 & $\begin{array}{l}\text { Overall, using blogs in my learning } \\
\text { was a good experience. }\end{array}$ & $\begin{array}{c}3 \\
(0.0)\end{array}$ & $\begin{array}{c}19 \\
(5.7)\end{array}$ & $\begin{array}{c}26 \\
(35.8)\end{array}$ & $\begin{array}{c}5 \\
(49.1)\end{array}$ & 3.62 & .740 \\
\hline N=53 Cronbach's alpha $=0.787$ & \\
\hline
\end{tabular}

Authors: Dr Tse-Kian Neo, Associate Professor and Dean,

Faculty of Creative Multimedia, Multimedia Unversity, Cyberjaya, Malaysia

Email: tkneo@mmu.edu.my

Dr Mai Neo, Associate Professor and Dean,

Institute of Postgraduate Studies, Multimedia University, Cyberjaya, Malaysia

Email: neo.mai@mmu.edu.my Web: http:/ / mmu-my.academia.edu/DrMaiNeo

Wai-Jing Kwok, Yeen-Ju Tan, Chen-Haw Lai and Che Embi Zarina

Faculty of Creative Multimedia, Multimedia University, Cyberjaya, Malaysia

Please cite as: Neo, T. K., Neo, M., Kwok, W. J., Tan, Y. J., Lai, C. H. \& Zarina, C. E.

(2012). MICE 2.0: Designing multimedia content to foster active learning in a

Malaysian classroom. Australasian Journal of Educational Technology, 27(1), 857-880.

http:/ / www.ascilite.org.au/ajet/ajet28/neo.html 